Alphonse $\mathrm{L}$. Pinart, the French naturalist, who is engaged in a scientific exploration of Alaska, announces his arrival at Unalaska on May 24, and his intended departure at an early day for Nus. gajak. We hope to lay before our readers, from time to time, the important features of the progress of this expedition. - A correspondent of the Weekly writes to report the occurrence of a lunar rainbow at his residence, Oxford Depôt, New York, on the 2nd July last. At nine o'clock in the evening of that day a heavy rain-storm came up from the west, and when the sky was about half obscured a very distinct and beautiful rainbow made its appearance, having an arc estimated at $90^{\circ}$. The top of the bow was a deep blue, the lower side red; and between the two colours appeared a distinct hazy green. The moon was just rising at the time, and the perfect bow was visible for about five minutes, and partially distinguishable for a quarter of an hour.

\section{SOCIETIES AND ACADEMIEN}

Paris

Academie des Sciences, July 24.-No elections took place, but the members were rather numerous, as a secret committee is to take place at the close of the public sitting to discuss the merits of candidates. The secret committee was rather long, and a lively conversation took place. $M$. Lacaze-Duthiers was presented at the head of the list. After him came M. Gervais, and on the third line MM. Dareste and Alphonse Milne-Edwards. Each of these four gentlemen has respectable qualifications. M.A. MilneEdwards is the son of M. Milne-Edwards, the great naturalist, who is chief of the section where the vacancy is to be filled up. -In the public sitting, M. Chasles gave a new series of theorems, which are to be demonstrated; but as they belong to a certain family of properties, and arranged seriutim, the very enunciation of them is more than half of the work to be done. "These theorems are sixty in number, and are styled "Properties of geometrical curves relating to their harmonic axes," but none of them are of primary importance.-An observation was sent to M. Leverrier with respect to the great bolide of the I8th July, which was seen at La Guerche (Cher). Its course was from $\epsilon$ Cygni to $\alpha$ Pegasi. No track but a great quantity of light, first white and afterwards red; local time inh. $5 \mathrm{~m}$., duration $3^{\prime \prime}$. -Details were given by $M$. Sainte-Claire Deville of a bolide seen on the night of $x 7$ th and isth March. A bolide was seen also in Italy by P. Denza at Moncalieri, but the accounts do not agree. It is supposed that P. Denza saw another bolide, which is not much to be wondered at, as the I8th of March is considered to be favourable for the appearance of large meteors, and P. Denza says he saw many of them on that very night when there was no moon. -P. Secchi sends a new letter "On solar protuberances and the relations between faculæ and spots; the communication cannot be condensed.-M. Delaunay presented a new volume of the "Aunales de l'Observatoire National," the twenty-third of the collection, and full of observations. - The Academy appointed a com mittee for the Bordin prize, which will be given for the best memoir on the Comparison of the Natural Productions of South Africa, South America, and South Australia, as well as intermediate lands. The programme was very cleverly drawn up, and answers most admirably to the controversies on the "Origin of Species." The election was contested, and MM. Milne-Edwards, Brongniart, Elie de Beaumont, Quatrefages, and Decaisnes, were appointed. "The report will be written with great care. An invitation was addressed to the Academy by the Intermational Congress, which will meet at Antwerp on the 22nd August; no formal answer is given to it.-M. Berthelot, who for some time had not published any report in the Comptes Rendus, attempted to give a very clever explanation of the immense explosive force of some organised compounds derived from nitric acid. He says that there is an intimate union between nitric acid and the organic matter upon which the acid has acted. But the action takes place with scarcely any heat being produced. The heat is kept in reserve within the molecules of the explosive body for future action. His theoretic views are supported by calorimetrical experiments. Thus an equivalent of nitric acid being employed in the manufacture of nitro-benzine, gives only 4,300 calorics, and in the fabrication of nitric ether 6,000 calorics. Nitric ether being inexplosible, the greater explosibility of nitrobenzine can be explained by the r, 700 calorics.-M. Milne Edwards presented, in the name of $\mathrm{M}$. Joly, a paper on a transformation. which Palingentra virgo undergoes before its final metamorphosis. These intermediate and imperfect metamorphoses are less scarce and exceptional than was supposedM. Ledillat, who is a very learned Arabic scholar, as well as a very good astronomer, sent a paper to support his previous assumption relative to the immense number of Arabic words which are to be found in the French language. His views will be supported by every Frenchman acquainted with the Arabic language, and there are a good many owing to the occupation of Algiers, and all these Arabic etymologies were omitted systematically by M. Littré in his great Etymological Dicionary.-An electro-magnetic machine on a new plan for exciting continuous currents was exhibited on the I7th by M. Gramme, who was highly prassed by $M$. Jamin. M. Bazin raised a claim for the priority of the invention, and a paper placed by him in the hands of the perpetual secretary in the sitting of the Ioth July was opened. The description given by him is similar. But the construction of M. Gramme's machine was certainly in full operation by that time. - We learn with much concern that $M$. Saigey, a very clever philosopher and mathematician, who had contributed many very valuable papers to the Comples reizdus, and to several scientific periodicals, and who was the author of many interesting books on scientific matters, died from actual want during the Communist insurrection. He was found dead in his room on the I 9 th of May, after having been left unassisted during more than three days. M. Saigey was a genuine free thinker and a Republican by heart. He was expelled from the Normal School when twenty-four years old, under the Bourbons, in consequence of his liberal opinions. He remained true to his colours during his whole life, had never a single appointment from the State, and died of starvation when seventy-four years olit.

Juiy 31.-M. Faye in the chair.-M. Lacazes-Duthiers was elected a member by a large majority to fill the room of $M$. Longet. The new academician is a very accurate observer, who inaugurated his scientific career by discovering the extraordinary reproductive system of corals by the inspection of corals living on the Algerine sea coasts. Every year he has spen: his summers at some sea-side station in order to enlarge his knowledge of inferior organisms. He will be a very useful member. - The election for a free member will take place on August 7. M. Belgrand, a meteorologist and an engineer, will very likely be returned. Some opposition is expected, although accurding to every probability it will not be successful.-A letter from $M$. Janssen was read with respect to the observation of the next total eclipse, but the discussion was postponed till after the next meeting of the Section of Astronomy, which intends to propose an expedinion.

\section{BOOKS RECEIVED}

ENGilish - Handbook of British Fungi, 2 vols. : M. C Cooke (Macmillan and Co.). - Sir Isaac Newton's Principia, edited by Sir W. Thomson and H. Blackburn (Glasgow: J. Maclehose).-A Digest of Facts relating to the Treatment and Utilisation of Sewage, and edition. W. H. Corfield (Macmillan and Co.). - The Estuary of the Firth and Adjoining Districts Viewed Geologically : D. M. Home (Edinburgh : Edmonston and Douglas).

\section{CONTENTS}

PAGE

The Organisation of Local Scientific Effor't , . . . . $28 \mathrm{r}$ KinGSLEY"S "At LASt." . . . . . . . . . . . . . 282 OuR Book SHELF . . . . . . . . . . . . . . . . . 28 LETTERS TO THE EDITOR:-

Science Teaching in Schools, \&ci-W. M. WiLlians, F.C.S. . . 285 Cramming for Examinations.-T. A. ORNE . . . . . . . . 285

Volcano near Celebes.-A. B. MeYer . . . . . . . . . . 286

Notes . . . . . . . . . . . . . . 286

The British Association,-Edinburgh Meeting, I871 . . . 288

Section A.-Ssctional Proceedings . . . . . . . . . . . 29

Section B.-Sectional Proceedings . . . . . . . . . 29

Section C.-Sectional Proceedings . . . . . . . . . . . 292

Section D -Opening Address by Prof. Altern Thomson. . . . 293

Section E.-Opening Address by Col. H. Yule, C. B. . . . . . 297

Section F.-Opening Address by Lord NEAVES . . . . . . . . . 298 Scientific Intelligence from America . . . . . . . . . . 298 Sociertes and Academies . . . . . . . . . . . . . . 300 Books ReCEIVED . . . . . . . . . . . . . 300 